\title{
Study on the Protection and Tourism Development Mode of Puxian Opera*
}

\author{
Lizhen Wei \\ Fuzhou University \\ Xiamen, China 361024
}

\author{
Zhixiong Huang \\ Fuzhou University \\ Xiamen, China 361024
}

\begin{abstract}
The Puxian opera is one of the oldest operas in China's existing operas. It has a history of more than 900 years and is the crystallization of the wisdom of the Chinese nation, reflecting the life style and value judgments of ancient people. In the era of rapid economic development, the survival status of the Puxian opera is not ideal. With the state's attention to the protection of opera art, people are also aware of the threat of disappearing. Under the background of the great development of tourism, this paper attempts to protect the Puxian opera with appropriate tourism development. The article begins with an overview of Puxian opera and briefly explains its current status of protection and tourism development. Second, it analyzes the necessity and feasibility of tourism development. Finally, it constructs a specific model for the development of protective tourism for the Puxian opera.
\end{abstract}

Keywords-Puxian opera; tourism development

\section{INTRODUCTION}

\section{A. Introduction of Puxian Opera}

The Puxian opera was formerly known as the Xinghua Opera and later renamed the Puxian opera. It is mainly popular in Putian City and the adjoining Puxian dialect area. It is one of the ancient local opera dramas in China. It was listed in the National Intangible Cultural Heritage List in 2006. The Puxian opera originated in the Tang Dynasty, formed in the Song Dynasty, and flourished in the Qing Dynasty with more than 8,000 copies of transcripts, more than 5,000 repertoires, more than 1,000 qu tunes, and more than 300 kinds of gongs and drums. ${ }^{[1]}$ The Puxian opera has survived thousands of years of vicissitudes, and it still retains its vitality. This is why it has extremely rich artistic accumulation, and is also a precipitation of regional culture and folk customs. According to the document "Puxian Opera", the Puxian opera has certain origin relations with Daqu in the Tang Dynasty and Song Dynasty and the Nanxi in Yuan dynasty with the reputation of "living fossils of Chinese opera" and "relics of the Song and Yuan Nanxi" ${ }^{[2]}$.

\section{B. The Protection of Puxian Opera and the Present Situation of Tourism Development}

In recent years, Putian City has vigorously implemented the revitalization project of the Puxian Opera and issued a

*Fund projects: Social science planning project of Fujian Province in 2016(FJ2016B215) series of policies and measures such as the "Implementation Opinions on the Inheritance Protection and Development of the Puxian Opera". The Puxian Opera Heritage Protection Center of Putian City has been established and the city has carried a series of activities, such as "supporting the opera to enter the grassroots", "launching dramas into rural areas" and additive activities of modern civilization Xiaoxi of Puxian Opera to carry on the protection, inheritance and development of Puxian Opera ${ }^{[3]}$. However, the issue of protection and inheritance is still unsatisfactory. As performance artists and successors grow older or die in individual drama theater groups and young people in the new generation lack the love and study of the However, the issue of protection and transmission is still unsatisfactory. As individual performance artists and successors grow older or die in individual drama theater groups, young people in the new generation lack the love and study, Puxian Opera faces pretty grate threat of being lost. In addition, there are an array of other problems about Puxian Opera, for example, the government's low support, lack of a correct guidance mechanism, blind inheritance have misled traditional art, lacked the novelty of new screenplays, and the emergence of the aging of the main audience, which have brought great hinder on the protection of Puxian opera and tourism development. So far, from the point of view of tourism development, the protection research and practical projects of Puxian Opera are still relatively few and lack systems.

\section{ANALYSIS OF THE NECESSITY AND FEASIBILITY OF TOURISM DEVELOPMENT IN PUXIAN OPERA}

\section{A. The Necessity of Tourism Development of Puxian Opera}

1) Facilitating the protection, inheritance and development of Puxian Opera: Puxian opera is the first batch of national intangible cultural heritage. It is the essence of traditional ethnic culture and the manifestation of regional culture and folk customs as well as an important tourism resource. Tourism development is conducive to the protection of inheritance and development of Puxian opera. Adam Smith believes that emotions or inner feelings can produce various behaviors. ${ }^{[4]}$ In other words, when visitors appreciate and like the Puxian opera, they will arouse the local residents' love and recognition of the Puxian opera, and then, make them have the conscious awareness of protecting and inheriting this culture. When residents get more satisfactory economic 
income and improve their quality of life in tourism development, they perceive the benefits of tourism development. This will enable local residents to invest more time and energy in the protection and inheritance of the Puxian opera. At the same time, the development of the tourism industry also brings in more economic income, which can inject more funds for the protection of the Puxian opera and achieve the purpose of win-win.

2) Promoting the development of tourism and local economy: With the continuous development of society, tourism, one of the third industries, is the main driving force for social development in the future. More and more people are now willing to spend their time and money on tourism. Many people are curious about the development of traditional culture and the changes of ancient and modern life. As a cultural tourism resource, proper development of cultural tourism in Puxian opera can not only enrich tourism products and attract tourists, but also promote tourism and local economic development. Under the background of the protection of intangible cultural heritage and the great development of tourism, with the aim of protecting and promoting the Puxian opera, the means of tourism development and the purpose of win-win situation, it is a general trend to combine the protection of Puxian Opera with tourism development.

\section{B. The Feasibility of Tourism Development in Puxian Opera}

1) Rich traditional drama repertoire: Putian is known as the "Zoulu of the Seashore" and the "Reputed Literary State". It is well-known for its well-developed culture, rich cultural heritage, and rich traditional drama. The representative plays include "After Reunion", "Chuncao Breaks into Court" and "No. One Scholar and Beggar". The "White Rabbit" of Carp Troupe in Puxian Opera won "the best Traditional Drama Award" in the fifth Drama Festival of China- Paris, France and has been widely praised by all circles both at home and abroad. These outstanding and rich repertoires laid a solid foundation for the tourism development of Puxian Opera.

2) Unique regionalism and culture nature: The Puxian opera has strong local characteristics and unique performing arts. This has a close relationship with the rich folk culture and festive celebration activities in the Puxian area. As long as there are larger folk activities, there will be performances of the Puxian opera. And it has been formed into a kind of local cultural wealth. Art originates from life. Puxian area has formed a unique Puxian culture by its own unique regional culture and humanistic culture, which includes both the remains of the ancient Minyue culture and the descendants of the Central Plains culture from the Han and Tang dynasties. Puxian culture is the cultural basis for the survival of the Puxian Opera. Its unique regionality and culture indicate the direction of tourism development for the Puxian Opera.

3) National and local policy support: In recent years, with the continuous strengthening of national and local research and protection and promotion of operas, in 2015 the state issued the "Several Policies on Supporting the Inheritance and Development of Traditional Operas". In 2017, Fujian Province issued the "The Implementation Project of Fujian Opera Protection and Inheritance and Development". In 2018, Putian City issued a series of policies and measures including "Implementation Opinions on Inheritance and Protection and Development of the Puxian Opera". National and local governments have successively introduced these policies and measures for the protection of traditional operas, which have played a guiding role in the protection, inheritance, and development of the Puxian opera.

4) Regional economic and tourism development advantages: Putian City is located in the middle of coastal Fujian Province and is one of the famous historical and cultural cities in Fujian and the economic zones on the west bank of the Taiwan Strait. It has a unique geographical location and rich tourism resources. On December 23, 2016, Director of the Tourism Bureau of Putian City Lin Hua said in an interview with this reporter that the Municipal Tourism Administration had issued the "Planning Implementation Plan of the Tourism Tourism Plan of the Putian City (2017-2021)", which aims to build tourism brands center on "fresh Fujian, "Mazu Holy Land and Beautiful Putian". Relying on unique resources, the city will develop global tourism, and build Putian into a cultural tourism destination of Mazu, a coastal eco-resort, and a Buddhist cultural center among Maritime Silk Road countries. By 2021, the city expects to receive over 50 million tourists, total tourism revenue exceeding RMB 50 billion, and promotes the transformation and upgrading of the tourism industry. ${ }^{[5]}$ These policies have even helped the tourism development of the Puxian opera, and it is imperative to rely on the "global tourism special action" to promote the development of protective tourism.

\section{STUDY ON THE PROTECTION AND TOURISM DEVELOPMENT MODE OF PUXIAN OPERA}

\section{A. Infrastructure Construction}

Infrastructure construction is the most basic development mode in the tourism development process of Puxian Opera. It belongs to traditional tourism forms and mainly includes museums, cultural villages, folk festivals, and cultural and art festivals. This model can only focus on protection and inheritance, but it cannot be developed with great intensity. In the process of tourism development of the Puxian opera, it is necessary to combine the characteristics of the Puxian opera, but also to meet the needs of tourists. This requires that the cultural connotation be displayed through the combination of static display and dynamic display of the Puxian opera.

1) Establish Puxian Opera museum: The establishment of the Puxian Opera Museum can organize and preserve the precious historical data of the Puxian Opera, which helps to better protect the authenticity of the Puxian opera and show its truest to the visitors. However, the museum forms are static displays. Not only does it lack of innovation, but also can not interact with tourists. In the current construction of museum 
facilities, the application of new media technologies has become a new trend ${ }^{[6]}$. Therefore, in the construction of the Puxian opera museum, the new media technology can be used to make the Puxian opera displayed through pictures, text, music, video, etc., and the use of new media technology can also make the static museum form "live."The exhibition area has static display and dynamic display. The static exhibition area includes data exhibition area and item exhibition area. The information exhibition area includes the history and culture of the Puxian Opera, precious scripts, and performance stills while the items exhibition area includes the props, costumes, faces and musical instruments of the Puxian opera. The dynamic exhibition area can be the tourism experience area of Puxian opera. Through the use of high-tech methods for scene experience design, visitors are personally in the scene, interacting with professional actors, and personally experiencing the profound cultural heritage of the Puxian opera to arouse their interest in the Puxian opera.

2) Construction of Puxian Opera culture village: The Puxian Opera cultural village is a type of theme park. It mainly uses a certain village as a unit carrier to demonstrate its culture and it is one of the emerging tourism development models. The construction of the Puxian Opera culture village can reflect its culture from multiple perspectives, enabling tourists to further understand the excellent cultural resources of the Puxian Opera and improve the consciousness of protection of the Puxian Opera. The Puxian Opera Cultural Village is a microcosm and epitome of the Puxian Opera. It enables visitors to quickly understand the Puxian Opera within a limited time and space featured by a strong appreciation and can interact with tourists in time to increase the participation experience of tourists. The Puxian Opera cultural village should integrate the performance experience of the Puxian Opera, the crafts, food, entertainment, shopping, and propaganda and protection of the Puxian Opera in order to meet the various needs of tourists and also to achieve the goal of propaganda and protection of the Puxian Opera.

3) Hold Puxian Opera art festival: The Puxian Opera art festival can be based on folk celebrating activities, and also can be held in a certain time. In this way, it can fetch a group of spectators for this opera, and promote the development of local tourism at the same time. The perfect combination of this kind of drama and tourism will be a new form of tourism development in the future. We need to take into account the entertainment and artistry of cultural activity, and the participation and experience of tourists in the design of activities related to Puxian Opera arts festival. For example, hold some competitions for Puxian Opera including performance competition and singing competition. We can also carry out some Puxian Opera exchange activities, so that more people can understand and fall in love with Puxian Opera, and then we can protect, inherit and develop Puxian Opera and promote the development of local tourism.

\section{B. Cultural and Creative Design}

Cultural and creative design mode refers to combine Puxian Opera with cultural and creative industries, deeply explore the profound cultural deposits embodied in Puxian Opera, and develop the cultural knowledge of the Puxian Opera through creative concepts and technical means, forming a systemic, universal and disseminating industry.

1) Build Puxian Opera brand: Puxian Opera is one of the oldest operas in China. Since Puxian Opera enjoys the title of "Living Fossil of Chinese opera", which shows its unique characteristic. The cultural and creative design model of Puxian Opera is to explore the uniqueness of Puxian Opera, package it into a powerful tourism project with profound cultural connotation with the help of tourism industry design, and build its unique cultural brand of Puxian Opera. The creation of Puxian Opera brand can be started from two aspects: the first is to conduct a creative layout for excellent repertoire and integrate it into the film and television works. Through the film and television works, the opera can be displayed in a new form. The second is to look for representative figures in the repertoire to develop their IP image, and to make thematic series cartoon combined with the repertoire. These can be used to publicize its brand and make Puxian Opera a distinctive cultural brand in the Puxian area. This can not only attract more tourists, but also can promote the development of the tourism industry. Meanwhile, a further protection, inheritance and development for Puxian Opera also can be made.

2) Development of tourism cultural and creative products: During the design and development of Puxian Opera tourism, the development of tourism cultural and creative products of Puxian Opera is an indispensable link. It is of certain significance to develop the corresponding tourism cultural and creative products appropriately and reasonably, and the development of it is also a protection and development of Puxian Opera. The tourism cultural and creative products related to e Puxian Opera can be audiovisual products of the Zhuxian Opera, IP image dolls, some cultural and creative products printed with the Puxian Opera elements including cultural shirts and mobile phone shells, and other relatively ordinary products. Putian City, known as "hometown of arts and crafts", mainly develops wood carving, jade carving, stone carving, mahogany furniture and other crafts. Therefore, in the development of cultural and creative products of Puxian Opera, we can use the intangible cultural heritage handicraft in Puxian area to make and develop some high-end tourism cultural and creative products with Puxian Opera elements, such as small crafts, pendants, ornaments, and so on. ${ }^{[7]}$ The development of tourism cultural and creative products of Puxian Opera can not only promote the development of related industries, but also expand the influence of Puxian Opera, and further strengthen the protection of Puxian Opera.

3) New media promotion: The consumption behavior of people in modern society has been influenced by the mass media, so we can widely publicize Puxian Opera with the help 
of news media. We can propagandize and popularize the thematic series cartoon produced by the promotional video and excellent repertoire of Puxian Opera through the Internet and TV platforms, select inspirational stories related to Puxian Opera, the scenes of the Puxian Opera arts festival, and tourism cultural and creative products and publish them on newspapers, forums, mobile APP (micro-blog, WeChat) smart terminals and other platforms for propagandizing and popularizing the tourism development of Puxian Opera, and make greater efforts to expand publicity. This will not only conduct tourism publicity, but also achieve the purpose of protecting Puxian opera.

\section{CONCLUSION}

Each place has its own way of supporting its own inhabitants, and people in one place have cultivated their featured culture.

As a typical representative of a culture, Puxian Opera has enriched our traditional culture and is an indispensable part of our traditional opera. We combine the cultural protection of the Puxian Opera with tourism, and establish effective and reasonable development measures, so that the Puxian Opera can be revitalized again. This not only can protect, carry forward and develop the Puxian Opera, and allow people to identify with the Puxian Opera, but also can contribute to the development of local tourism economy.

\section{REFERENCES}

[1] Weng Xin. Activate the Thinking on Living Fossil of the Southern Opera in the Song and Yuan Dynasties: A Brief Discussion on the Prosperity and Development of Fujian Xianxian Opera [J]. Art and Literature for the Masses, 2010, (13): 46-47. 翁歆. 激活宋元南戏化 石的思与考: 浅谈福建莆仙戏的繁荣与发展 [J]. 大众文艺, 2010, (13): $46-47$.

[2] Yang Meixuan, Xie Baochi. Puxian Opera [M]. Fujian: Fujian People's Publishing House, 2003. 杨美煊,谢宝伬. 莆仙戏曲 [M].福州: 福建人 民出版社,2003.

[3] Huang Guoyong. Opera Life in Folk-A rural Performance Observation of Puxian Opera [N]. China Culture Daily 2018,3 9,(05). 黄国勇. 戏曲 生命在民间一一萳仙戏乡村演出观察 [N].中国文化报 2018,3 9,(05).

[4] (England) Adam Smith. The Theory of Moral Sentiments [M]. Beijing: Central Compilation\&Translation Press, 2008:15. ( 英 ) 亚当 - 斯 密. 道德情操论 [M]. 北京: 中央编译出版社, 2008:15.

[5] Chen Yongzhong. Promote Industrial Integration and Develop Global Tourism [N]. Meizhou Daily 2016,12,29,(01). 陈永忠. 推动产业融合 发展全域旅游 [N].湄洲日报 2016,12,29,(01)

[6] Liu Li. New Trends of the Application of New Media Technology in Museums: Read the New Media Consortium Horizon Report: 2011 Museum Edition [J]. Chinese Museum, 2012(4)：102-105. 刘莉．新 媒体技术在博物馆应用的新趋势: 读《新媒体联盟地平线报告 2011 年博物馆版》报告 [J]. 中国博物馆, 2012(4): 102-105.

[7] Dai Biting, Guo Lini. Protective Tourism Development Research on Puxian Opera the Intangible Cultural Heritage of Chinese Traditional Opera [J]. Journal of Neijiang Normal University 2016(8): 56-60. 戴碧 婷, 郭丽妮. 戏曲类非物质文化遗产莆仙戏保护性旅游开发研究 [J]. 内江师范学院学报 2016(8): 56-60. 